\title{
Comparison between the usefulness of preparations: Acid Pla Tan Liquid and Efektywne Mikroorganizmy in the control of Nosema spp. infection in bees
}

\author{
KONSTANTY ROMANIUK, JERZY WILDE*
}

\author{
Department of Parasitology and Invasive Diseases, Faculty of Veterinary Medicine, University of Warmia and Mazury, \\ Oczapowskiego 13, 10-719 Olsztyn, Poland \\ *Apiculture Division, Faculty of Animal Bioengineering, University of Warmia and Mazury, \\ Słoneczna 48, 10-710 Olsztyn, Poland
}

\section{Romaniuk K., Wilde J.}

\section{Comparison between the usefulness of preparations: Acid Pla Tan Liquid and Efektywne Mikroorganizmy in the control of Nosema spp. infection in bees}

\section{Summary}

Bearing in mind that there is no effective medication to control nosemosis, the authors assessed the usefulness of Acid Pla Tan Liquid [AP] and Efektywne Mikroorganizmy [EM] in the management of this disease in bees. Prior to field tests, we carried out laboratory examinations for the toxicity of the preparations in cages with bees, and then on colonies infected with Nosema spp. The evaluation of the effectiveness of the preparations was carried out on 36 colonies infected with nosemosis. In bees administered syrup containing the tested preparations at concentrations: $2 \mathrm{ml}, 1 \mathrm{ml}, 0.5 \mathrm{ml}, 0.25 \mathrm{ml}$, and $0.125 \mathrm{ml}$ per $1 \mathrm{l}$, we did not observe abnormal behaviors or workers' deaths. Bees in complete colonies with therapeutic syrup containing AP administered 3 times at a dose of $1 \mathrm{ml} / 1 \mathrm{l}$, and with $\mathrm{EM}$ at a dose of $2 \mathrm{ml} / 1 \mathrm{l}$ behaved similarly. Worker bees from these colonies left the hive in a usual manner to fly for forage, brought pollen, found their way back home accurately, young bees emerged from their cells, the queen laid eggs, and young bees raised brood. After 15 days from the completion of the treatment, we found out that AP eliminated Nosema spp. infection at $100.0 \%$, and EM at 42.9\%. The autumn control triple administration of AP at a dose of $1 \mathrm{ml} / 1 \mathrm{l}$, and EM at a dose of $2 \mathrm{ml} / 1 \mathrm{l}$, to colonies with different intensity of Nosema spp. infection proves a higher effectiveness of AP (75\%) than EM $\mathbf{( 5 8 . 3 \% ) . ~ A ~ m e a n ~ o f ~ a ~ s i g n i f i c a n t l y ~ l o w e r ~ n u m b e r ~ o f ~ s p o r e s ~ w a s ~ o b s e r v e d ~ i n ~ c o l o n i e s ~ f r o m ~ g r o u p ~ A P ~ a s ~ c o m p a r e d ~}$ both to the control group and group EM, in which the number of spores was nevertheless significantly lower than in the control group.

Keywords: Nosema spp., control, Acid Pla Tan Liquid, Efektywne Mikroorganizmy, honeybee colonies

Nosemosis is becoming the second hardest-to-treat disease in bees after varroosis. A particular increase in the prevalence of nosemosis in Poland took place when fumagillin had been withdrawn from the treatment of the disease, and in the cases when, apart from Nosema apis, bee colonies were additionally infected with another microsporidian species of the Nosema genus, i.e. $N$. ceranae. Bees affected by $N$. ceranae die quickly, usually outside the hive, without showing any prior clinical symptoms $(5,9,14)$. In contrast to $N$. apis infections, the incidence of diseases caused by $N$. ceranae remains at the same level throughout the honey flow season $(9,11)$. And even though infections by Nosema spp. subside in winter $(4,7)$, they constitute a serious problem in European and Polish apiaries $(12,15,16)$. The analyses of dead bees collected by the authors of the study from big and small apiaries near Olsztyn, Poland, over the last years, showed that the extensiveness of infection in big apiaries was ca $40 \%$, and in small ones: $60-70 \%$. Among the factors contributing to such an infection of bee colonies with Nosema spp. is not only the lack of an effective medication in the country, but also the inadequate preparation of colonies for wintering, the lack of diversified pollen, inappropriately treated varroosis, the lack of hygiene in the apiary, atypical, often warm winters as well as long and rainy springs $(1,19)$. Despite numerous investigations of the impact of the parasite, its role in honey bee mortalities is highly debated $(2,3,6,8,21)$.

To date the, course of nosemosis in apiaries in Poland has been often alleviated by beekeepers with such preparations as Nozevit, ApiHerb, salicylic acid, the 
water extract of birch ash, wormwood decoction with an addition of salicylic acid and vitamin $\mathrm{C}$, as well as peroxide $(17,18,20)$ administered in sugar syrup at specific times of the season.

Bearing in mind that there is no effective medication to control Nosema spp. infection in bees, the aim of the studies was to assess the usefulness of two preparations used for years in vertebrates to prevent bacterial, viral and fungal diseases.

\section{Material and methods}

In 2012 a trial treatment was carried out with a use of the Acid Pla Tan Liquid preparation [AP] - a complementary compound (liquid) feed produced by Czesław Szmender's company (www.etos.net.pl), used for years in the basic prevention of bacterial and fungal infections of the digestive system in poultry. The preparation contains: formic acid, sorbic acid, sorbic acid salt, hydrolyzed, water-soluble tannins, and standardized natural extract substances, i.e. capsaicin, carvacrol and cinnamaldehyde. The activity of the preparation consists in a synergistic effect of its components on different forms of bacteria and fungi (22).

The other preparation that was used in the control of nosemosis in bees was Efektywne Mikroorganizmy [EM], produced by EKO-Agrotech (www.eko-natura.eu). The preparation contains selected and specifically composed live cultures of lactic acid bacteria, yeast, actinobectaria and plant extracts from 20 herbs. The composition of microorganisms in the preparation, which is a strong antioxidant, shows an entirely favorable effect on animal health. Besides, lactic acid bacteria in the preparation produce enzymes effectively enhancing the durability of honey and bee bread (13).

The evaluation of the usefulness of preparations AP and $\mathrm{EM}$ in the control of nosemosis was carried out in the years 2012-2013 in two apiaries near Olsztyn, Poland. Prior to field tests, laboratory examinations of the toxicity of the preparations were carried out in special hoarding cages with bees, and then the toxicity and effectiveness of nosemosis control in complete bee colonies naturally infected with Nosema spp. were also assessed.

Laboratory evaluation of toxicity of AP and EM to bees. 11 worker groups (A. mellifera) were set up, each consisting of 5 wooden cages $(12 \times 12 \times 4 \mathrm{~cm})$ with 501 -day-old workers in each. Each cage had a glass front screen as well as ventilation and feeding slots. The workers were fed (between 2-8 July) with sugar syrup $(1: 1$, w/v) ad libitum using inner feeders. When assessing the toxicity of preparations, therapeutic syrup was served in PET bottles with 3-4 holes of $3 \mathrm{~mm}$, in diameter, made in the bottle neck. A bottle filled with therapeutic syrup was closed with a screw cap and placed on the inner cover in such a way that the holes in bottle necks were between combs to make the syrup accessible for bees. Syrup administered in the described way in July was willingly taken by bees. A 2-liter bottle was usually emptied within 48 hours. In each group, the syrup was supplemented with AP or with EM at different concentrations: $2 \mathrm{ml}, 1 \mathrm{ml}$, $0.5 \mathrm{ml}, 0.25 \mathrm{ml}$, and $0.125 \mathrm{ml}$ per 11 of syrup. Group 11 was fed only with sugar syrup and served as control. The cages were kept in an air-conditioned chamber $\left(26^{\circ} \mathrm{C}\right.$ and $65 \%$ relative humidity). Dead workers were removed every day. It was also observed the behavior of bees, and every day for 6 sub- sequent days were controlled the tempo of consuming the syrup by bees.

Field evaluation of toxicity of AP and EM to bee colony and their effectiveness in summer Nosema spp. control. Out of several dozen colonies in the apiary, 14 colonies infected with Nosema spp. were selected. The colonies kept in Wielkopolski-type hives, numbering c. 20 thousand bees and ten occupied combs (with 6 worker combs filled with a brood in all stages of development, 4 combs with food) were randomly divided into two groups. From 16 July to 25 July 3 times at 3-day intervals each colony was administered 21 of therapeutic syrup containing $1 \mathrm{ml}$ of AP and $2 \mathrm{ml}$ of EM per 11 of syrup, which were applied in frame feeders.

The behavior of bees and their foraging activity, as well as the egg-laying activity of the queen were assessed daily after the application of the therapeutic syrup.

Field evaluation of AP and EM effectiveness in autumn Nosema spp. control. To assess the effectiveness of Nosema control, in the latter half of August 2012, apiaries considerably infected with Nosema spp. were chosen. Out of 58 colonies, 36 colonies infected with Nosema spp. spores were selected. The colonies kept in Wielkopolski-type hives with $360 \times$ $260 \mathrm{~mm}$ frames, numbering c. 30 thousand bees and twenty occupied combs (with 12 worker combs filled with a brood in all stages of development, 8 combs with food) were randomly divided into 3 groups, 12 colonies in each, i.e.: AP, EM, and control. Therapeutic syrup containing: $1 \mathrm{ml} \mathrm{AP} \mathrm{(group} \mathrm{AP)}$ or $2 \mathrm{ml} \mathrm{EM} \mathrm{(group} \mathrm{EM)} \mathrm{per} 11$ was administered 3 times at 3-day intervals in the amount of 21 per colony during each feeding ( $1^{\text {st }}$ feeding: 22 Aug 2012). The assessment of the effectiveness of the preparations was carried out on $25 \mathrm{Sept}$. 2012, and 12 Oct. 2012. Moreover, living bees after wintering were also examined (31 Mar. 2013).

In order to study bees with the presence of Nosema spp. spores and to avoid sampling newly emerged, uninfected bees, a sample of ca 100 bees were taken from the peripheral combs without brood, containing food only. From those bees a single sample consisting of 60 abdomens of worker bees was crushed with a mortar and pestle in $60 \mathrm{ml}$ of distilled water and spores were counted using haemocytometer method (15). This procedure was applied in all experiments.

The one-way ANOVA analysis was used to calculate the mean number of Nosema spp. spores; one-factor ANOVA was carried out. The significance of differences between the means was determined by the Duncan's multiple range test. Calculations were performed with the Statistica v. 10 software.

\section{Results and discussion}

Laboratory evaluation of toxicity of AP and EM for bees. It was found out that therapeutic syrup containing the tested preparations was willingly consumed by bees. In the group of worker bees fed with syrup containing $2 \mathrm{ml}$ AP per 11 , single bees were observed to die - on day 4, 5 and 6. Altogether, 6 bees died in each of the 5 cages with 50 workers in the group. In group EM, 4 workers died on average. In group AP $1 \mathrm{ml}$ and $0.5 \mathrm{ml}$, the mean number of dead workers was 3.9 and 1.9 , respectively. In cage tests, bees receiving therapeutic syrup with the tested preparations did not display abnormal behavior that would suggest the toxic effect of the preparations (Tab. 1). 
Tab. 1. Laboratory evaluation of the toxicity of preparations: Acid Pla Tan Liquid [AP] and Efektywne Mikroorganizmy [EM] for bees in cage tests

\begin{tabular}{|c|c|c|c|c|c|c|c|}
\hline \multirow{2}{*}{$\begin{array}{l}\text { Content of } \\
\text { preparation } \\
\text { in } 1 \text { I of } \\
\text { sugar syrup }\end{array}$} & \multirow[t]{2}{*}{$\begin{array}{c}\text { Tested } \\
\text { preparation }\end{array}$} & \multirow{2}{*}{$\begin{array}{l}\text { No. of cages } \\
\text { in group } \\
\text { ( } 50 \text { bees in } \\
\text { each cage) }\end{array}$} & \multicolumn{5}{|c|}{$\begin{array}{l}\text { Mean number of dead workers during feeding } \\
\text { with sugar syrup containing tested preparations } \\
\text { Observation day }\end{array}$} \\
\hline & & & $1-3$ & 4 & 5 & 6 & Total \\
\hline \multirow[t]{2}{*}{$2 \mathrm{ml}$} & AP & 5 & 0 & 1.9 & 1.8 & 2.3 & 6.0 \\
\hline & $\mathrm{EM}^{*}$ & 5 & 0 & 0 & 1.9 & 2.1 & 4.0 \\
\hline \multirow[t]{2}{*}{$1 \mathrm{ml}$} & AP & 5 & 0 & 0 & 1.9 & 1.9 & 3.9 \\
\hline & EM & 5 & 0 & 0 & 0 & 1.9 & 1.9 \\
\hline \multirow[t]{2}{*}{$0.5 \mathrm{ml}$} & AP & 5 & 0 & 0 & 0 & 1.9 & 1.9 \\
\hline & EM & 5 & 0 & 0 & 0 & 0 & 0 \\
\hline \multirow[t]{2}{*}{$0.25 \mathrm{ml}$} & AP & 5 & 0 & 0 & 0 & 0 & 0 \\
\hline & EM & 5 & 0 & 0 & 0 & 0 & 0 \\
\hline \multirow[t]{2}{*}{$0.125 \mathrm{ml}$} & AP & 5 & 0 & 0 & 0 & 0 & 0 \\
\hline & EM & 5 & 0 & 0 & 0 & 0 & 0 \\
\hline Control & & 5 & 0 & 0 & 2.1 & 0 & 2.1 \\
\hline
\end{tabular}

Explanations: *sugar syrup at $2 \mathrm{ml}$ concentration was consumed by bees in smaller amounts.

Tab. 2. Field evaluation of the toxicity of preparations: Acid Pla Tan Liquid [AP] and Efektywne Mikroorganizmy [EM] for bees, and the number of Nosema spp. spores in the treated colonies (summer treatment)

\begin{tabular}{|c|c|c|c|c|c|c|c|c|}
\hline \multirow[t]{2}{*}{ Preparation } & \multirow{2}{*}{$\begin{array}{l}\text { No. of bee } \\
\text { colonies } \\
\text { infected with } \\
\text { Nosema spp. }\end{array}$} & \multirow{2}{*}{$\begin{array}{l}\text { Mean number }( \pm S D) \\
\text { of Nosema spp. spores } \\
\text { prior to treatment } \\
\text { (per } 1 \text { bee } \times 10^{6} \text { ) } \\
16 \text { Jul. } 2012\end{array}$} & \multicolumn{3}{|c|}{$\begin{array}{l}\text { Days of preparation administration } \\
\text { to bee colonies }\end{array}$} & \multicolumn{2}{|c|}{$\begin{array}{l}\text { Number of colonies } \\
\text { with Nosema spp. after } \\
\text { completing treatment }\end{array}$} & \multirow{2}{*}{$\begin{array}{c}\text { Mean number }( \pm \text { SD) } \\
\text { of Nosema spp. spores } \\
\text { after treatment } \\
\text { (per } 1 \text { bee } \times 10^{6} \text { ) } \\
17 \text { Aug. } 2012\end{array}$} \\
\hline & & & 18 Jul. 2012 & 22 Jul. 2012 & 25 Jul. 2012 & 03 Aug. 2012 & 17 Aug. 2012 & \\
\hline AP & 7 & $2.17^{\mathrm{a}} \pm 0.35$ & ns & ns & ns & 0 & 0 & 0 \\
\hline EM & 7 & $1.97^{\mathrm{a}} \pm 0.29$ & ns & ns & ns & 5 & 3 & $0.31 \pm 0.17$ \\
\hline
\end{tabular}

Explanation: ns - no symptoms of tested preparation toxicity on bees and brood observed during and after treatment; a differences are not statistically significant at $P \leq 0.05$

Field evaluation of the toxicity of AP and EM for bee colonies and their effectiveness in summer Nosema spp. control. Tests for Nosema spp. presence in living worker bees collected from treated colonies spp. infection decreased in all colonies to $0.97 \times 10^{6}$ per tested bee, on average. In EM group the number of colonies tested positive for Nosema spp. dropped to 9 ( $25 \%$ effectiveness), but the mean infection was signifion day 9 and 29 after completing the AP treatment did not show Nosema spp. spores, suggesting the $100.0 \%$ effectiveness of the preparation. In the group of colonies administered syrup with EM, Nosema spp. spores were found in 3 colonies after treatment (42.9\% effectiveness) (Tab. 2). The mean infection was lower in both groups $\left(0\right.$ and $0.31 \times 10^{6}$ in AP and EM group, respectively) than the infection observed before treatment $\left(2.17 \times 10^{6}\right.$ and $1.97 \times 10^{6}$ in AP and EM group, respectively). However, as there was no untreated control group, it is hard to assess to what extent a decrease in the degree of infection resulted from the application of tested preparations, and to what extent it should be linked to the natural course of infestation resulting from the seasonal growth of Nosema spp. in colonies.
Tab. 3. Effectiveness of preparations: Acid Pla Tan Liquid [AP] and Efektywne Mikroorganizmy [EM] in the reduction of the number of Nosema spp. spores

\begin{tabular}{|l|c|c|c|}
\hline \multicolumn{1}{|c|}{ Date of assessment } & Group & $\begin{array}{c}\text { No. of infected } \\
\text { colonies in group }\end{array}$ & $\begin{array}{c}\text { Mean number }( \pm \text { SD) of Nosema spp. } \\
\text { spores per } 1 \text { bee }\left(\times 10^{6}\right)\end{array}$ \\
\hline $\begin{array}{l}\text { Prior to administration } \\
\text { 22 Aug. 2012 }\end{array}$ & Control & 12 & $3.99^{\mathrm{a}} \pm 0.73$ \\
& AP & 12 & $4.05^{\mathrm{a}} \pm 0.58$ \\
\hline Post treatment & EM & 12 & $4.21^{\mathrm{a}} \pm 0.83$ \\
25 Sept. 2012 & Control & 9 & $2.22^{\mathrm{a}} \pm 1.49$ \\
& AP & 6 & $0.97^{\mathrm{c}} \pm 1.08$ \\
Post treatment & EM & 9 & $1.28^{\mathrm{b}} \pm 1.01$ \\
12 0ct. 2012 & Control & 10 & $2.32^{\mathrm{A}} \pm 1.36$ \\
& AP & 3 & $0.24^{\mathrm{Bc}} \pm 0.35$ \\
After wintering & EM & 5 & $0.97^{\mathrm{b}} \pm 0.76$ \\
31 Mar. 2013 & Control & 10 & $1.87^{\mathrm{a}} \pm 1.21$ \\
& AP & 6 & $0.60^{\mathrm{c}} \pm 0.45$ \\
\hline
\end{tabular}

Explanations: $\mathrm{a}, \mathrm{b}$ - differences are statistically significant at $P \leq 0.05$ for comparisons within the columns; A, B - differences are statistically significant at $P \leq 0.01$ 
cantly lower $\left(1.28 \times 10^{6}\right)$ than the infestation observed in control colonies $\left(2.22 \times 10^{6}\right)$.

A follow-up test carried out on 12 Oct 2012, i.e. 17 days after the previous assessment, showed that the number of colonies in which Nosema spp. were found dropped in group AP to 3 (75.0\% effectiveness), and in group EM to 5 (58.3\% effectiveness), with 10 infected colonies among control colonies. The significantly lowest level of infection was found in colonies from group AP $\left(0.24 \times 10^{6}\right)$, and the highest one in control groups $\left(2.32 \times 10^{6}\right)$.

After wintering, the number of colonies found to be infected with Nosema spp. in the control group increased to 10 , showing a significantly higher level of infection $\left(1.87 \times 10^{6}\right)$, which differed from the situation observed in group EM $\left(1.02 \times 10^{6}\right)$ where 6 infected colonies were found. The fewest colonies with Nosema spp. spores were found in group AP, in which bees were infected with the significantly lowest number of spores $\left(0.60 \times 10^{6}\right)($ Tab. 3$)$.

Bee colonies treated several times with the discussed preparations wintered well. Bees wintered better (less bee deaths during winter, as well as more combs covered by bees after winter) in group AP, where Nosema spp. spores were found only in 6 colonies out of 12 infected colonies prior to the administration of the preparation, while in group EM the result was 8 colonies out of 12 originally infected colonies. A significant reduction in the number of Nosema spp. spores in colonies fed with sugar syrup containing $1 \mathrm{ml}$ AP per 11 , as compared to EM treatment, indicates an advantage of AP over EM in nosemosis control. The higher effectiveness of AP can be attributed to its components that show a selective effect on unicellular pathogens of the bee gut. After penetrating into a bacterium or fungus cell, formic acid effectively disturbs protein synthesis and enzymatic pathways of cytoplasmic organelles, thus limiting the number of bacteria in the gut (22). Sorbic acid salt shows good water solubility but also very strong antibacterial and antifungal activity, while a multidirectional effect of hydrolyzed tannins effectively disturbs the living functions of many unicellular pathogens $(10,22)$. Moreover, tannin fractions show hydrophilic effect through overloading the water balance in the bee gut with inflammation; they also effectively bind to toxins produced by bacteria, fungi and protozoa. The preparation components likewise enhance the exploitation of food and stimulate physiological reactions in the digestive system; they also boost the immunological system (10). It is remembering, however, that the assay was conducted on colonies in which the species of Nosema was not identified, and it cannot be ruled out that different results can be achieved under infection with one or two species of Nosema but at different proportions.

Conclusions:

1. Acid Pla Tan Liquid at a dose of $1 \mathrm{ml}$ per 11 of syrup and Efektywne Mikroorganizmy at a dose of $2 \mathrm{ml}$ per 11 of syrup, administered 3 times at 3-day intervals during winter feeding do not cause any disruptions in the functioning of bee colonies.
2. In comparison to EM, Acid Pla Tan Liquid, as a diet supplement, more efficiently limits the development of Nosema spp in bee colonies and protects them against a high level of this infection.

\section{References}

1. Büchler R., Costa C., Hatjina F., Andonov S., Meixner M. D., Le Conte Y., Uzunov A., Berg S., Bienkowska M., Bouga M., Drazic M., Dyrba W., Kryger P., Panasiuk B., Pechhacker H., Petrov P., Kezic N., Korpela S., Wilde J.: The influence of genetic origin and its interaction with environmental effects on the survival of Apis mellifera L. colonies in Europe. J. Apicult. Res. 2014, 53, 205-214.

2. Chen Y. P., Evans J. D., Murphy C., Gutell R., Zuker M., Gundensen-Rindal D., Pettis J. S.: Morphological, molecular, and phylogenetic characterization of Nosema ceranae, a microsporidian parasite isolated from the European honey bee, Apis mellifera. J. Eukaryot. Microbiol. 2009, 56, 142-147.

3. Fries I.: Nosema ceranae in European honey bees (Apis mellifera). J. Invert. Pathol. 2010, 103, 73-79.

4. Gajda A.: Nosema ceranae in honeybee (Apis mellifera) colonies. Życie Wet. 2010, 82, 140-143.

5. Higes M., Garcia-Palencia P., Martín-Hernández R., Aránzazu M.: Experimental infection of Apis mellifera honeybees with Nosema ceranae (Microsporidia). J. Invertebr. Pathol. 2007, 94, 211-217.

6. Higes M., Martin-Hernandez R., Botias C., Bailon E. G., Gonzales-Porto A. V., Barrios L., Del Nozal M., Bernal J. L., Jimenez J. J., Palencia P. G., Meana A.: How natural infection by Nosema ceranae causes honeybee colony collapse. Environ. Microbiol. 2008, 10, 2659-2669.

7. Higes M., Martín-Hernández R., Meana A.: Nosema ceranae, a new microsporidian parasite in honeybees in Europe. J. Invertebr. Pathol. 2006, 92, 93-95.

8. Higes M., Meana A., Bartolomé C., Botías C., Martín-Hernández R.: Nosema ceranae (Microsporidia), a controversial $21^{\text {st }}$ century honey bee pathogen. Environ. Microbiol. Rep. 2013, 5, 17-29.

9. Klee J., Beasana A. M., Genersch E., Gisder S., Nanetti A., Tam D. Q., Chinh T. X., Puerta F., Ruz J. M., Kryger P., Message D., Hatjina F., Korpela S., Fries I., Paxton R. J.: Widespread dispersal of the microsporidian Nosema ceranae an emergent pathogen of the western honey bee, Apis mellifera. J. Invertebr. Pathol. 2007, 96, 1-10.

10. Lück E.: Food applications of sorbic acid and its salts. Food Addit. Contam. 1990, 7, 711-715

11. Martín-Hernández R., Meana A., Prieto L., Salvador A. M., Garrido-Bailón E., Higes M.: Outcome of colonization of Apis mellifera by Nosema ceranae. Appl. Environ. Microbiol. 2007, 73, 6331-6338.

12. Meixner M. D., Francis R. M., Gajda A., Kryger P., Andonov S., Uzunov A., Topolska G., Costa C., Amiri E., Berg S., Bienkowska M., Bouga M., Büchler R., Dyrba W., Gurgulova K., Hatjina F., Ivanova E., Janes M., Kezic N., Korpela S., Le Conte Y., Panasiuk B., Pechhacker H., Tsoktouridis G., Vaccari G., Wilde J.: Occurrence of parasites and pathogens in honey bee colonies used in a European genotype - environment - interactions experiment. J. Apicult. Res. 2014, 53, 215-229.

13. Olofsson T. C., Butler È., Markowicz P., Lindholm C., Larsson L., Vásquez A.: Lactic acid bacterial symbionts in honeybees - an unknown key to honey's antimicrobial and therapeutic activities. Int. Wound J. 2014, doi: 10.1111/iwj.12345 [Epub ahead of print].

14. Paxton R., Klee J., Korpela S., Fries I.: Nosema ceranae has infected Apis mellifera in Europe since at least 1998 and may be more virulent than Nosema apis. Apidologie 2007, 38, 558-565.

15. Pohorecka K., Bober A., Skubida M., Zdańska D.: A comparative study of environmental conditions, bee management and the epidemiological situation in apiaries varying in the level of colony losses. J. Apicult. Sci. 2014, 58, 107-132.

16. Pohorecka K., Bober A., Skubida M., Zdańska D.: Epizootic status of apiaries with massive losses of bee colonies (2008-2009). J. Apicult. Sci. 2011, 55, 137 -150 .

17. Romaniuk K.: Próba wykorzystania nadtlenku wodoru w profilaktyce i zwalczaniu nosemozy pszczół. Pszczelarstwo 2013, 54, 8-10.

18. Romaniuk K.: Przydatność popiołu $\mathrm{z}$ drewna brzozy w profilaktyce chorób pszczół. Pszczelarstwo 2013, 54, 22-23.

19. Siuda M., Wilde J., Woyke J., Jasiński Z., Madras-Majewska B.: Wintering Reserve Queens in Mini-Plus and 3-Comb Nuclei. J. Apicult. Sci. 2014, 58, 61-68.

20. Sokół R.: Badania wpływu kwasu acetylosalicylowego na pszczoły. Mat. XLI Naukowej Konferencji Pszczelarskiej, Puławy 2004, p. 40-41.

21. Webster T. C., Pomper K. W., Hunti G., Thacker E. M., Jones S. C.: Nosema apis infection in worker and queen Apis mellifera. Apidologie 2004, 35, 49-54.

22. Wertelecki T.: Quatro synergii-Acid Pla Tan Liquid. Polskie Drobiarstwo 2012 20, 20-22.

Corresponding author: prof. dr hab. Jerzy Wilde, ul. Słoneczna 48, 10-710 Olsztyn, Poland; e-mail: jerzy.wilde@uwm.edu.pl 